\title{
可変減衰ダンパーを用いた免震システムの変形抑止制御 DISPLACEMENT CONTROL METHOD OF BASE-ISOLATION SYSTEM USING VARIABLE DAMPING DEVICE
}

\author{
長島一郎*, 欄木龍 大**, 日比野 浩***, 高木政 美**** \\ Ichiro NAGASHIMA, Ryota MASEKI, Hiroshi HIBINO \\ and Masayoshi TAKAKI
}

\begin{abstract}
After 1995 Hyogoken-Nanbu earthquake, buildings equipped with base-isolation systems are steadily increasing in Japan. However, large displacement pulses and large ground velocities have been observed in the near-source region of 1999 Chi-Chi earthquake in Taiwan and this kind of strong ground motions may cause a large displacement response in base-isolation buildings and may lead to severe damage and possible collapse.

To counteract the excessive displacement response of base-isolation systems, we have developed a displacement control method of base-isolation systems using variable damping devices. This system is applied to a floor isolation system and the control performance is demonstrated by shaking table tests.
\end{abstract}

Keywords: Base-isolation, Semi-active control, Large displacement pulse, Isolation floor, Shaking table test 免震構造, セミアタティブ制御, 大変形パルス, 床免震, 振動台実験

\section{1. はじめに}

建物の耐震性能を飛躍的に向上させる免震技術は, 1995年の兵庫 県南部地震を契機に普及が進んでいる。ところが, 1999年台湾·集 集地震では, 断層近傍において長周期で速度レ゙ベルが極めて大きな 地震動が観測されでおり,このような地震動に対して免震構造物が 過大な変形を生じる危険性が指摘されている1) 3)。また, 建物が密 集する市街地では，敷地面積の制約から，建物周辺部に充分なス ペースを確保することが出来ず,特に既存建物のレトロフィット等 で免震技術が適用出来ない場合もある。

上述した課題に対妈して免震構造物の過大変形を抑止するには, 免震装置周辺部にストッパーを設ける方法が先ず考えられるが, ス トッパーの復元力特性を様々に設定しても(復元力が変形とともに 増大するハードニング型や復元力が一定値で頭打ちになる降伏型), 一定以上の変形に対しては強い衝撃力が発生し, 非免震構造物と同 等以上の応答せん断力が発生する危険性が指摘されている3)，4)。

これは, 装置周辺部の限られた範囲で作動するストッパーでは, 充分なエネルギー吸収が達成できないためであり, 衝突の危険があ る場合には, 免震装置部の減衰性能を高める方法が有効と考えられ る。すなわち, 衝突の危険の無い通常の地震時には減衰性能を低く 設定して, 従来の加速度応答低減効果を発揮させ, 衝突の危険のあ
る場合には減衰性能を高く設定して,加速度応答をある程度犠牲に しても免震層の变形を抑止する戦略である。このような目的に対し て,減衰性能が制御可能ないわゆるセミアクティブ制振システムの 応用が考えられる。

セミアクティブ制振システムは,少ないエネルギー投入で高い制 振性能が実現できることから,大地震までを適用範囲とした制振シ ステムとして近年活発に研究開発が行われて来ている。具体的に は, ブレースのon/offを利用する可変剛性機構5)や, オイルダンパー 6) 7) 8), 摩擦ダンパー9) -12), MRダンパー13) -16), ER ダンパー 17) 18) 等を利用する可变減衰機構が研究・開発されて来ており, 免震構造 物への応用研究も行わ扎ている9１0１9２01。

セミアクティブ制振システムの制御法では, 通常のパッシブダン パーでは実現できない高減衰を構造物に付加するアルゴリズムを開 発したり7) 8) 12), 最適制御理論やリアプノフ関数を用いる非線形制 御理論等に基づいたフィードバック制御則を応用することにより 14) 21) 22) 23)，パッシブ制振システムよりも制振効果を向上させて, 加速 度応答や変位応答を低減させることに主眼が置かれている。

免震構造物への応用についても目的は基本的に同じであり, 最適 制御やスライディングモード制御等を適用して,より広い周波数帯 域で制御性能を発揮させることにより, 通常の免震構造物と比べ
*大成建設(俶技術センター 主任研究員・博士 (工学)

** 大成建設秼技術センター 主任・工修

****大成建設(侏技術センター 主任研究員・工修

**** 大成建設㑣)技術センター チームリーダー・博士(丁学)
Chief Research Engineer, Technology Center, Taisei Corporation, Dr. Eng. Chief, Technology Center, Taisei Corporation, M. Eng.

Chief Research Engineer, Technology Center, Taisei Corporation, M. Eng.

Team Leader, Technology Center, Taisei Corporation, Dr. Eng. 
て,免震層の変形を同等以下に抑制しつつ, 加速度応答を更に低減 させる効果が報告されている9１5）19）20。しかしながら，大地震時 の酎震安全性を向上させるための免震構造物において，セミアク ティブ制御を付加することにより，中小地震時の加速度応答を更に 低減させることの有用性については, 今後更なる検討が必要と思わ れる。

本研究では, 減衰性能が制御可能なオイルダンパーを用いて, 免 震層に生じる過大な変形を抑止する制御法を開発し, 床免震システ ムへ適用してその有効性を実証した。本制御法では, 免震層の基準 振幅値を設定し，一定時間後の予測振幅値との相対誤差に基づい て, 減衰性能を時々刻々切替え, 免震層の变形が常に一定值に近付 くように制御する。これにより, 変形が過大にならない地震動レべ ルの範囲では減衰性能を低く設定して,通常の免震構造物と同等の 加速度応答低減効果を発揮させ,衝突の危険のある場合には減衰性 能を高く設定して, 加速度応答の増加をある程度許容して, 免震層 の変形を抑止する効果を発揮させる。

本論文では, 床免震システムの制御に用いた減衰性能可変型才イ ルダンパーの基本特性と, 免震層の過大変形抑止を実現する制御 法, 振動台実験による性能実証結果とシミュレーション解析につい て述べる。

\section{2. 可変減衰ダンパーの基本特性}

本研究では,電磁比例りリーフ弁により減衰力が無段階に制御可 能なオイルダンパーを使用した ${ }^{24)}$ 。最大減衰力は $14.7 \mathrm{kN}$, ストロー クは土10cmである。図1の油圧回路図に示す通り，本ダンパーは 作動油の流れが一方向のユニフロータイプであり,伸縮方向の各々 にアンロード弁を配置し，減衰力がほほ０の状態も実現できる。実 験では $24 \mathrm{~V}$ の直流電源を使用し, 電流制御のアンプにより電磁比例 リリーフ弁を制御した。

電磁比例リリーフ弁への指令電圧を変化させた場合の, ピストン 速度一減衰力の試験結果を図 2 に，試験状況を写真 1 に示す。図 2 からわかる通り，減衰力はリリーフ前の調圧弁（オリフィス）の特 性が支配的な部分（第一勾配部）と，リリーフ後の特性（第二勾配 部)に分か礼ている。リリーフ後の減衰力は指令電圧を $0 \mathrm{~V}$ から $5 \mathrm{~V}$ の範囲で增減させることで制御が可能である。

\section{1 ダンパー特性の同定}

解析では, 減衰力のリリーフ前後の特性を, 各々直線近似するこ ととした。同定結果を図 2 に実線で示す。試験結果と同定結果は, 指令電圧が小さく，かつ速度が大きな領域で若干差が見られるが， 全般的に概ね良く対応している。指令電圧を $\mathrm{V}(\mathrm{V})$, 速度を $\dot{x}_{d}(\mathrm{~cm} /$ s）とすると，同定式は以下の通りである。

1) $1.03<\mathrm{v} \leq 5$ の時 $\quad: F\left(\mathrm{v}, \dot{x_{d}}\right)=\min \left(F_{1}, F_{2}\right)$

$$
\text { ただし }, F_{1}=c_{1} \cdot \dot{x}_{d}, \quad F_{2}=c_{2} \cdot \dot{x}_{d}+N_{a} \cdot \mathrm{v}+N_{b}
$$

2) $0 \leq \mathrm{v} \leq 1.03$ の時 $\quad: \dot{F}\left(\mathrm{v}, \dot{x_{d}}\right)=\left(N_{c} \cdot \mathrm{v}+c_{3}\right) \cdot \dot{x}_{d}$

3）アンロード時 $\quad: F\left(\dot{x}_{d}\right)=c_{0} \cdot \dot{x}_{d}$

ここで，上記パラメータ值は下記の通りである。 $c_{0}=0.0263 \mathrm{kN} \cdot \mathrm{s} / \mathrm{cm}, c_{1}=5.03 \mathrm{kN} \cdot \mathrm{s} / \mathrm{cm}, c_{2}=0.187 \mathrm{kN} \cdot \mathrm{s} / \mathrm{cm}$ $c_{3}=0.1149 \mathrm{kN} \cdot \mathrm{s} / \mathrm{cm}, N_{a}=2.3839 \mathrm{kN} / \mathrm{V}, N_{b}=-2.4524 \mathrm{kN}$ $N_{c}=0.0699 \mathrm{kN} \cdot \mathrm{s} / \mathrm{cm} / \mathrm{V}$

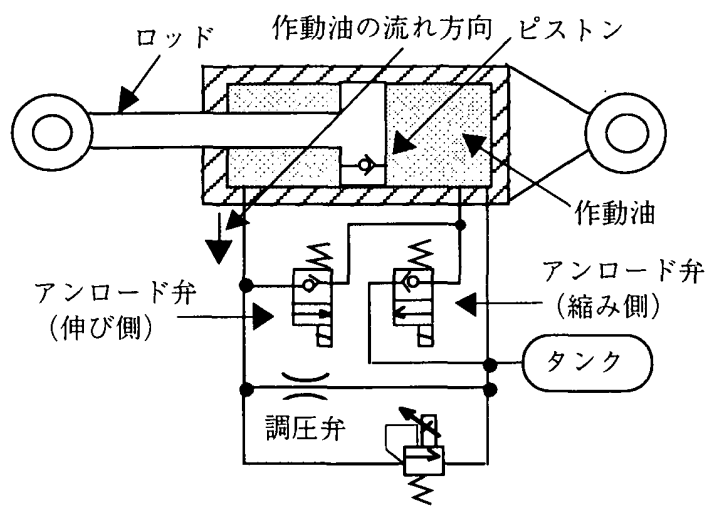

電磁比例リリーフ弁

図 1 油圧回路図（文献 ${ }^{24)}$ より引用加筆）
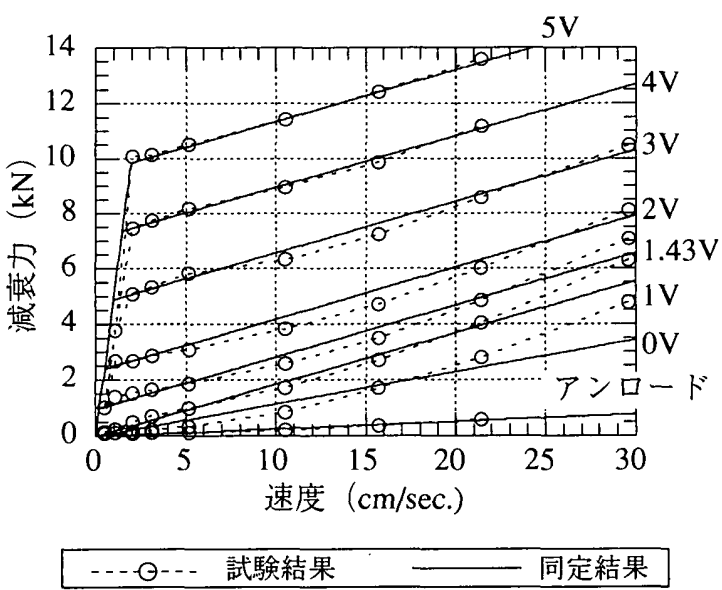

図 2 減衰力一速度関係

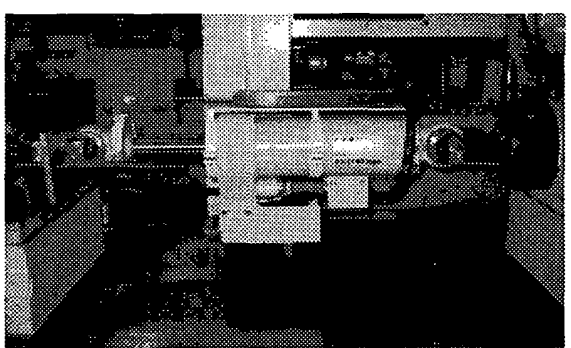

写真 1 オイルダンパー試験状況

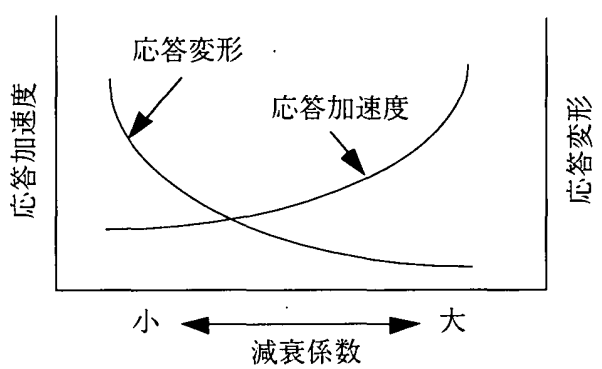

図 3 応答加速度と応答変形のトレードオフ

\section{3. 可変減衰ダンパーの制御法।}

免震構造物の応答加速度と応答变形には, 図3に示すような減衰 係数を介したトレードオフがあると考えら机る。そこで本研究では 先ず, 減衰力がピストン速度に比例するように, 電磁比例リリーフ 

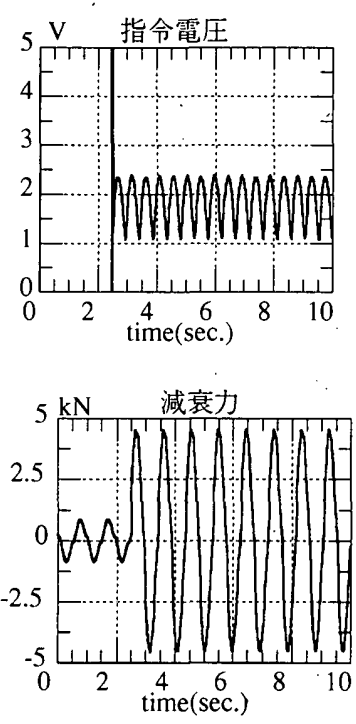

(a) 時刻歴波形 $(0.5 \mathrm{kN} \cdot \mathrm{s} / \mathrm{cm})$
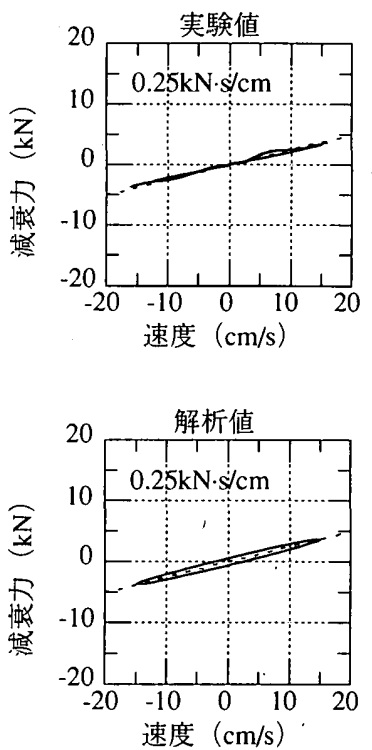

速度 $(\mathrm{cm} / \mathrm{s})$
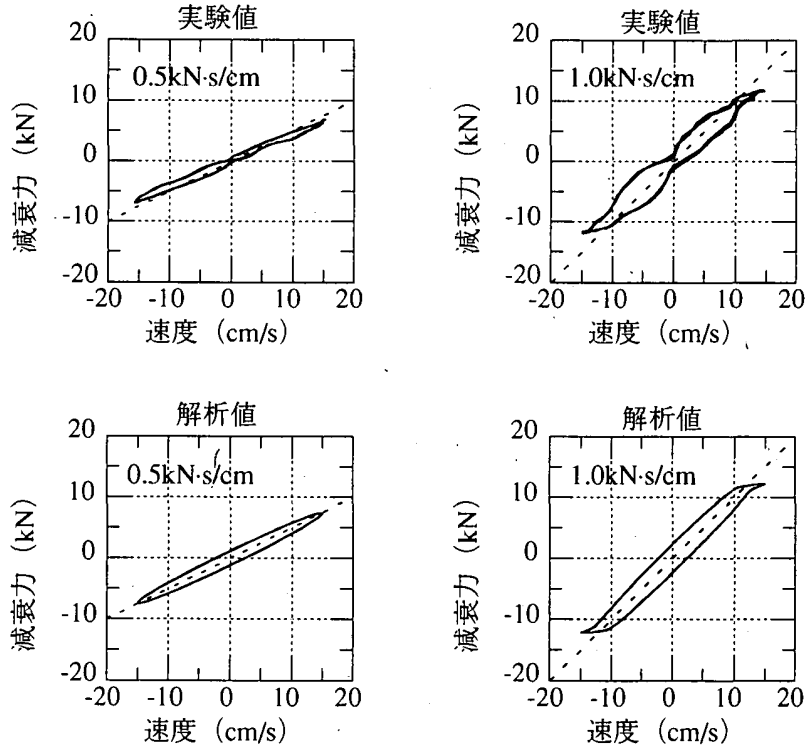

(b) 速度一減衰力関係

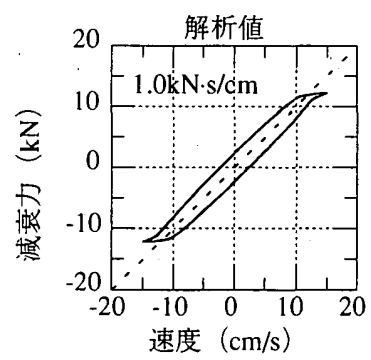

図 4 減衰係数制御の特性

弁への指令電圧を変化させて減衰係数の制御を実現する。次に, ア クティブマスダンパーの振幅制御用に開発した可変ゲイン制御法 25 を援用し,ダンパー変形の基準振幅值と一定時間後の予測振幅值に 基づいて減衰係数を制御することで,過大変形を抑止する制御法を 開発した。

リリーフ荷重を直接制御する方法も考えられるが, 減衰係数制御 に比べて最大応答加速度や最大応答变形どリリーフ荷重の相関が明 瞭ではないこと, 単純にリリーフ荷重を増減させるだけでは残留変 形が生じやすい等の理由により,本研究ではリリーフ荷重制御より も減衰係数制御の方法を採用した。

\section{1 減衰係数の制御}

減衰係数の設定值を $c$ （ただし,$c_{3} \leq c \leq c_{1}$ ）とすると 2.1 の同定 式を用いて電磁比例リリーフ弁への指令電圧 $\mathrm{v}$ は，以下のように 決定できる。

1) $c_{2} \leq c \leq c_{1}$ の時

2) $c_{3} \leq c \leq c_{2}$ の時

$$
\mathrm{v}=\left\{\left(c-c_{2}\right) \cdot \dot{x_{d}}-N_{b}\right\} / N_{a}
$$

$$
\mathrm{v}=\left(c-c_{3}\right) / N_{c}
$$

減衰係数を $0.5 \mathrm{kN} \cdot \mathrm{s} / \mathrm{cm}$ に設定した場合の, 正弦波加振に対する指 令電圧と減衰力の時刻歴波形を図4 (a) に例示する。指令電圧の初 期値を $5 \mathrm{~V}$ に設定したため, 制御開始時の 2.5 秒付近に $5 \mathrm{~V}$ のスパイ クが見られるが，以後指令電圧は安定している。

次に, 減衰係数を $0.25 \mathrm{kN} \cdot \mathrm{s} / \mathrm{cm}, 0.5 \mathrm{kN} \cdot \mathrm{s} / \mathrm{cm}, 1.0 \mathrm{kN} \cdot \mathrm{s} / \mathrm{cm}$ に設定した 場合の速度一減衰力関係を, 実験值と解析值を合わせて図4(b)に例 示する。図中点線が目標値である。速度と減衰力には若干の位相ず れがあるが, 概ね意図した減衰係数の制御が実現できている。速度 と減衰力の位相ずれは, 減衰力がリリーフ荷重に達する場合 (本例 では減衰係数が $1.0 \mathrm{kN} \cdot \mathrm{s} / \mathrm{cm}$ の場合) に，特に顕著である。指令電庄 に対応するダンパー減衰力が発生するまでに, $10 \mathrm{msec} の$ 時間遅れを 仮定して解析した，ピストン速度一減衰力関係を図4(b) 下段に示 すが，上段の実験値と良く対応している。

\section{2 変形抑止制御 (連続可変制御)}

制御アルゴリズムを図5に示す。本アルゴリズムは以下のステッ プから成っている。

Step1 $: i=0$ として減衰係数に初期値 $c_{\text {init }}$ を設定する。

Step2: $i=i+1$ として, 現時点のダンパー振幅值 $x_{d}$ と速度 $\dot{x}_{d}$ を計測 する。

Step3 : $x_{d}$ と $\dot{x}_{d}$ から $\Delta \mathrm{T}$ 秒後の予測振幅 $\tilde{x}_{d}$ を計算する。

$$
\tilde{x_{d}}=x_{d}+\Delta \mathrm{T} \cdot \dot{x_{d}}
$$

Step4 : 振幅值の所定基準値 $X_{d T}$ （以下基準振幅值と呼ぶ）と予測振 幅 $\tilde{x}_{d}$ との相対誤差 $\beta_{i}$ を評価する。

$$
\beta_{i}=\left|\frac{\tilde{x_{d}}}{X_{d T}}\right|-1.0
$$

Step5 : $\beta_{i}$ を用いて減衰係数 $c_{i}$ を增減する。

$$
c_{i}=c_{i-1}+\Delta c \cdot \beta_{i}
$$

ここで, $\Delta c$ は減衰係数の増分值である。増加時 $\left(\beta_{i}>0\right)$ と減少時 $\left(\beta_{i} \leq 0\right)$ で異なった值を設定出来るようにしている。

Step6：減衰係数 $c_{i}$ を, 上限値 $c_{\max }$ と下限値 $c_{\min }$ の範囲で決定する。 Step7：ダンパーに減衰係数の指令值を出力する。

\section{4. 振動台実験による性能確認}

3.で提案した可変減衰ダンパーの制御法の有効性を実証するた め, 本論文では床免震システムを対象として, 振動台実験による性 能検証実験を実施した。

\section{1 床免震システムの概要}

可変減衰ダンパーを適用する床免震システムの外観を写真 $2 に$ 示 す。本システムは，2次元免震装置，鉄骨架台，フリーアクセス床 （平面寸法 $3 \mathrm{~m} \times 3 \mathrm{~m} ）$ から構成され，床上に鋼製重鍾を設置してい る。2 次元免震装置は, 中心部が円弧状の直線状レールと, 軸受け 部にテフロン材を使用した車輪部から成る1次元免震装置が, 直交 


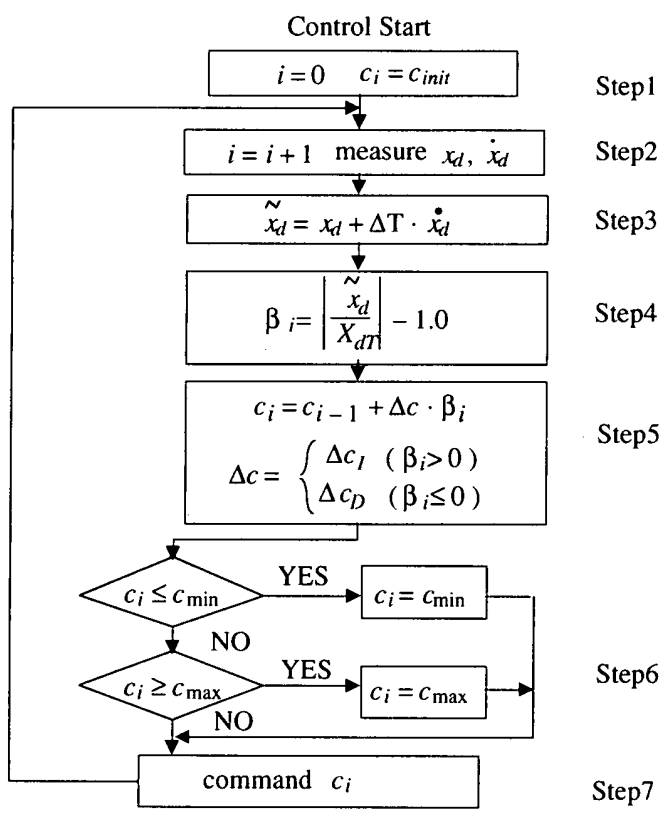

図 5 変形抑止制御のアルゴリズム（連続可変制御）

する形で2段に重ねられている。可変減衰ダンパーは, 振動台と根 太間に設置している。尚, 加振実験は水平 1 方向に対して行った。

床免震システムの試験体図面を図6に示す。免震床の变形と加速 度は, 図中に示す位置で計測した。力学モデルを図7に示す。免震 装置の車輪部の静摩擦特性とその速度依存性を, 速度の関数として 近似して，下式によりモデル化した26)，27)。

$$
\text { 静摩擦特性: } \quad \mathrm{F}=M g \cdot \mu_{S}: \frac{1-e^{-\alpha x}}{1+e^{-\alpha \dot{x}}}
$$

$$
\text { 速度依存性： } \quad \mu=\mu_{\max }-\left(\mu_{\max }-\mu_{S}\right) \cdot e^{-\beta|\dot{x}|}
$$

ここで, $M$ は免震装置の支持質量 $\left(7.239 \times 10^{3} \mathrm{~kg}\right), g$ は重力加速度, $\mu_{S}$ は静摩擦係数 $(0.034), \mu_{\max }$ は動摩擦係数の最大値 $(0.054)$, 摩 擦特性を規定するパラメー夕 $\alpha=5.0, \beta=0.4$ とした。

尚, 免震装置レール部復元力の第一勾配に対応する, 本床免震 ステムの固有周期の解析值は, 1 次が 2.73 秒 $(0.367 \mathrm{~Hz}), 2$ 次が 0.026 秒 $(38.8 \mathrm{~Hz})$ である。

\section{2 正弦波加振による基本性能確認}

周期 1.5 秒の正弦波で, 加速度振幅を漸増漸減させる加振を行い, 変形抑止制御の有無による床免震システムの応答を比較検討した。

変形抑止の制御パラメータは，以下のように設定した。

$c_{\text {init }}=c_{0}=c_{\min }=0.1149 \mathrm{kN} \cdot \mathrm{s} / \mathrm{cm}, c_{\max }=1.0 \mathrm{kN} \cdot \mathrm{s} / \mathrm{cm}$

$\Delta c=0.0025 \mathrm{kN} \cdot \mathrm{s} / \mathrm{cm}$ （増加時）, $0.00125 \mathrm{kN} \cdot \mathrm{s} / \mathrm{cm}$ （減少時）

$X_{d T}=1.5 \mathrm{~cm}, \Delta \mathrm{T}=0.375 \mathrm{~s}$ (加振周期の $1 / 4$ に設定), 制御周波数 $200 \mathrm{~Hz}$ 本制御を用いると, 正弦波加振時の免震床の応答変形は, 基準振 幅値 $X_{d T}$ に対して，下式の值に自動調整される（以下，この振幅值 $x_{a d}$ を調整振幅と呼ぶ)ことが明らかにされており25)，28)，本ケース では $1.26 \mathrm{~cm}$ である。

$$
x_{a d}=\frac{\pi}{2} \cdot \frac{X_{d T}}{\sqrt{1+\left(\frac{2 \pi}{T} \cdot \Delta \mathrm{T}\right)^{2}}}
$$

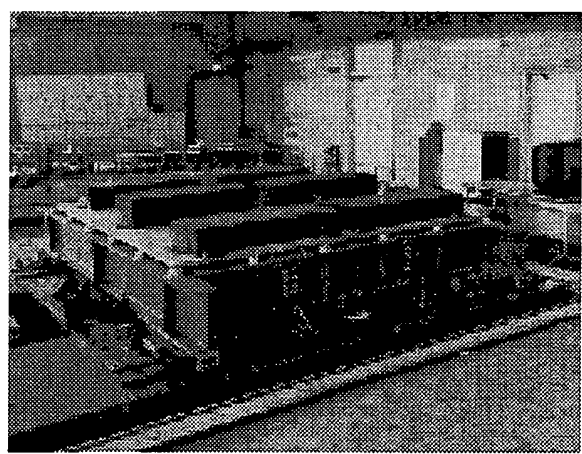

写真 2 床免震システムの外観

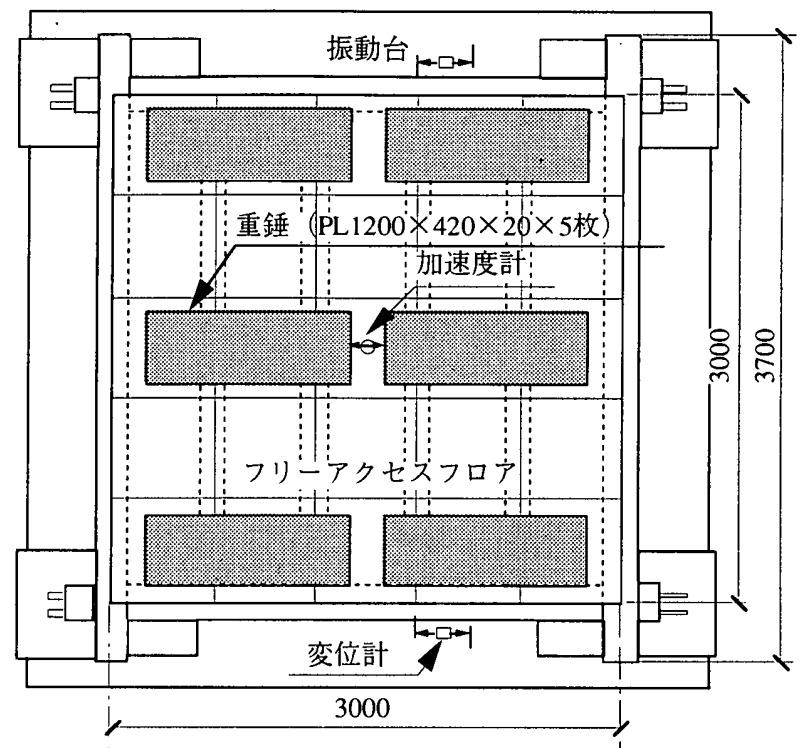

(a) 平面図

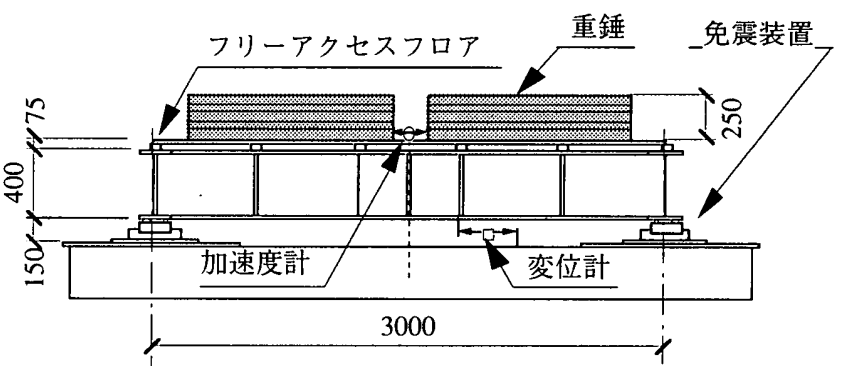

(b) 立面図

図 6 床免震システムの試験体図面

ここで, $T$ は制御対象の卓越周期に合わせ机ば良い。通常は，1次 固有周期に設定すれば良いが，本例では加振周期に合わせて 1.5 秒 とした。

図8に入力加速度と免震床の応答加速度, 応答变形, 減衰係数の 指令值の時刻歴波形を示す。非制御では応答变形が大きく増幅する のに対し, 制御により減衰係数が変化し, 応答加速度は若干大きく なるものの,応答変形はほほ調整振幅以内に制御されていることが わかる。

\section{3 地震波加振による性能実証}

ダンパーの制御を行わない(アンロード) 場合, 减衰係数を一定 に制御する場合, 変形抑止制御を行う場合の各々について, 振動台 

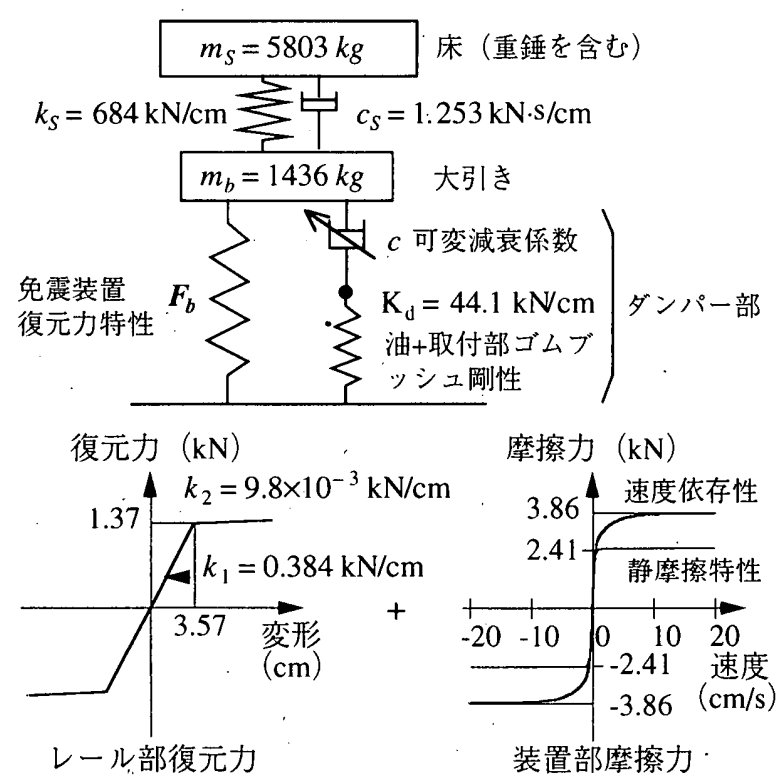

免震装置の復元力特性

図 7 床免震システムの力学モデル

による加振実験を行った。減衰係数一定制御は, 通常のパッシブダ ンパーとの性能比較のために実施した。尚, 免震床は 1 階に設置さ れるものと想定し，加振波として地震動波形を使用することとし た。

\section{（1）実験条件}

加振波：El-Centrol940NS，Hachinohel968NS

入力加速度：50Gal から 400Gal まで50Gal ピッチで増加

減衰係数一定制御 $: c=0.1,0.25,0.5,1.0 \mathrm{kN} \cdot \mathrm{s} / \mathrm{cm}$

変形抑止制御：ダンパーをアンロードにした状態から制御を開始し $\left(c_{\text {inii }}=c_{0}=c_{\text {min }}=0.0263 \mathrm{kN} \cdot \mathrm{s} / \mathrm{cm}\right)$, 減衰係数が初めて増加 $\left(\beta_{i}>0\right) し$ た時点以後はアンロード弁を閉じて $\left(c_{\min }=0.1149 \mathrm{kN} \cdot \mathrm{s} / \mathrm{cm} ; 1\right.$ 次モー ド減衰定数で $34 \%$ に相当）制御を行った。その他の制御パラメー 夕は以下の通り設定した。

$c_{\max }=1.0 \mathrm{kN} \cdot \mathrm{s} / \mathrm{cm}, \Delta c=0.125 \mathrm{kN} \cdot \mathrm{s} / \mathrm{cm}$ （増加時）, $0.003 \mathrm{kN} \cdot \mathrm{s} / \mathrm{cm}$ （減少 時) $, X_{d T}=4.0 \mathrm{~cm}, \Delta \mathrm{T}=0.25 \mathrm{~s}$ ，制御周波数 $200 \mathrm{~Hz}$

尚, 変形抑止効果を上げるため減衰係数の増分值 $\Delta c$ は増加時の 方を大きくした。また， $c_{\text {max }}$ は変形抑止制御時のダンパー最大速度 が概ね30kine 程度に納まるように， $X_{d T}$ と共に設定した。この範囲 内であ机ば，ダンパー特性の同定精度が高いからである（図 2 参 照)。実際には, $c_{\max }$ を $1.0 \mathrm{kN} \cdot \mathrm{s} / \mathrm{cm}$ 以上に設定しても変形抑止効果に ほとんど差が無い事をシミュレーションで確認して設定した。

振幅の予測時間刻み $\Delta \mathrm{T}$ を 0.25 秒に設定した場合の, 免震床の実 際の振動周期に対する，基準振幅值 $X_{d T}$ と調整振幅 $x_{a d}$ の比率は, (1) 式から図9に示す通り評価できる。免震床の振動周期が 1 秒 1.5 秒程度の範囲で, 基準振幅値 $X_{d T}$ と調整振幅 $x_{a d}$ が概ね一致する ことがわかる。

$\Delta \mathrm{T}$ は，本来は免震床の固有周期との関係で決定すれば良いが， 本地震波加振奏験では加振波の3秒以上の長周期成分を予め除去し ており，ダンパー速度を抑制するために $c_{\text {max }}$ も大きく設定したた め, 免震床の 1 次振動モード成分は励起されにくく，それより短い 加振波の周期成分による応答変形が支配的になるため, 1 秒程度の
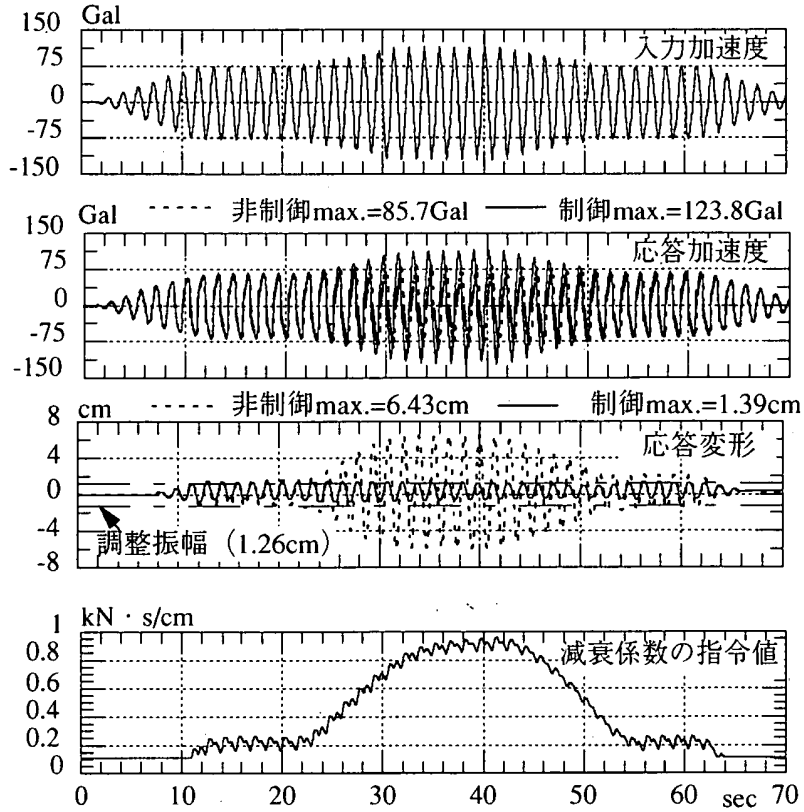

図 8 時刻歴波形（正弦波加振）

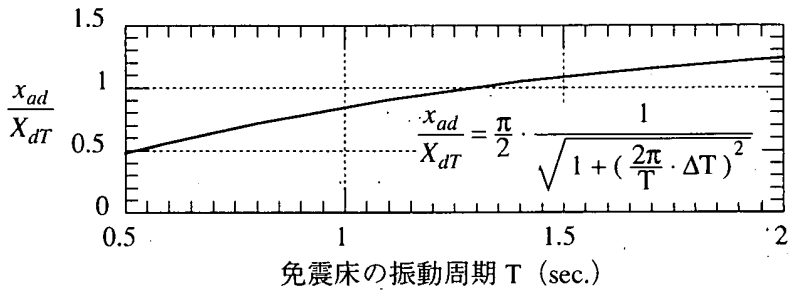

図 9 免震床の振動周期と調整振幅の関係

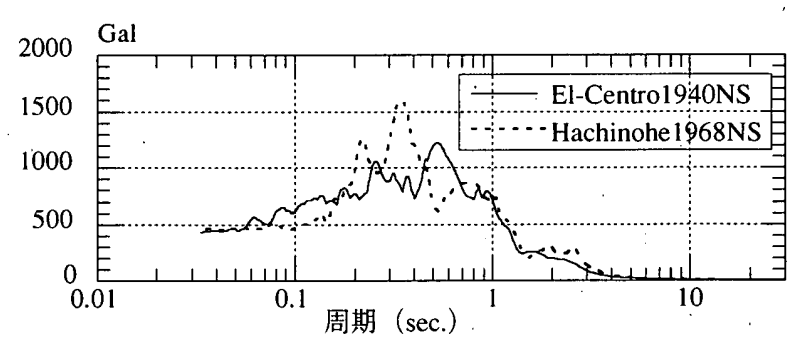

図 10 加振波の加速度応答スペクトル（減衰定数 $5 \%$ ）

振動周期を仮定してを 0.25 秒に設定した。

（2）実験結果

El-Centro1940NS と Hchinohe1968NS 加振の各々について, 400Gal 加振時の加速度応答スペクトル（減衰定数 $5 \%$ ）を図 10 に例示する。 また, 入力加速度に対する最大応答加速度と最大応答変形を比較し て図 11 に示す。变形抑止制御の場合, 両地震波加振共に $150 \mathrm{Gal}$ 加 振までは，アンロードと同じ最大応答を示している。一方, 200Gal 加振以上では, 最大応答変形は頭打ちになる傾向が見られ, 最大応 答加速度は, アンロードに比べて徐々に大きくなるが, 図中に示す 点線を越えないことから, 入力加速度よりも増幅はしていない。両 加振共に, 300Gal加振以上ではダンパー減衰力がリリーフ荷重に達 したため, 変形抑止効果が若干低下するものの, 400Gal加振時の最 大応答変形は，アンロードの $50 \%$ 以下に低減されている。

本実験では入力加速度が $150 \mathrm{Gal}$ 程度までは通常の免震効果を発 

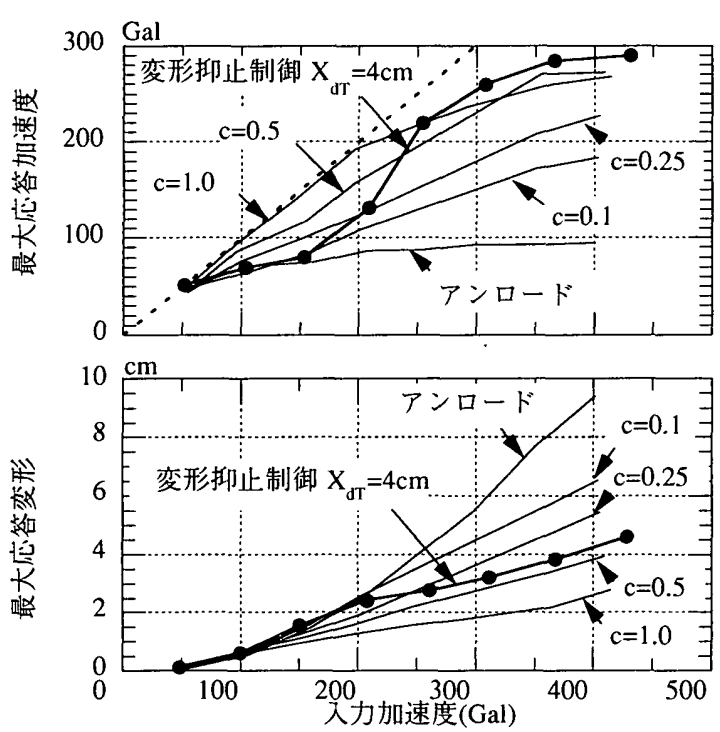

(a) El-Centro1940NS 加振
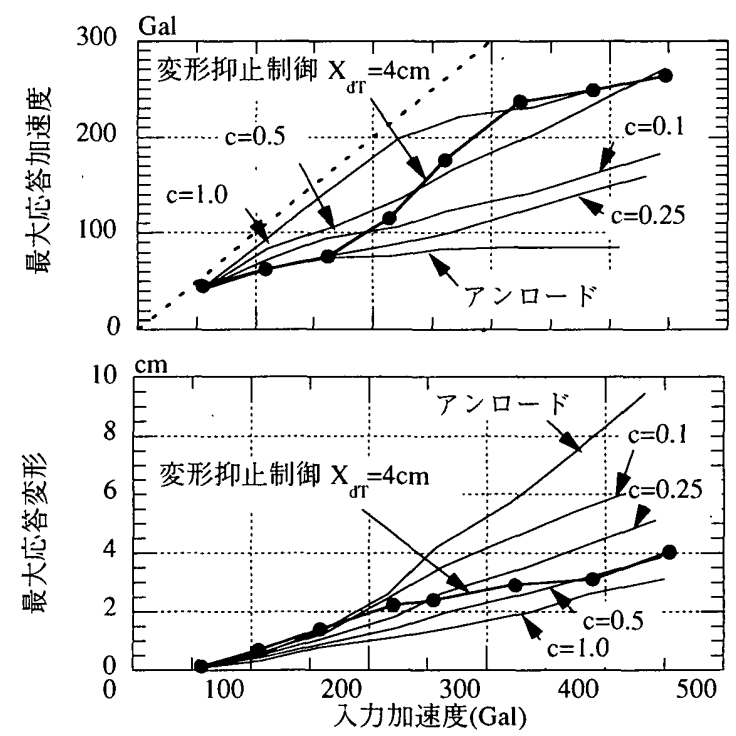

(b) Hachinohe 1968NS 加振

図 11 入力加速度と最大応答
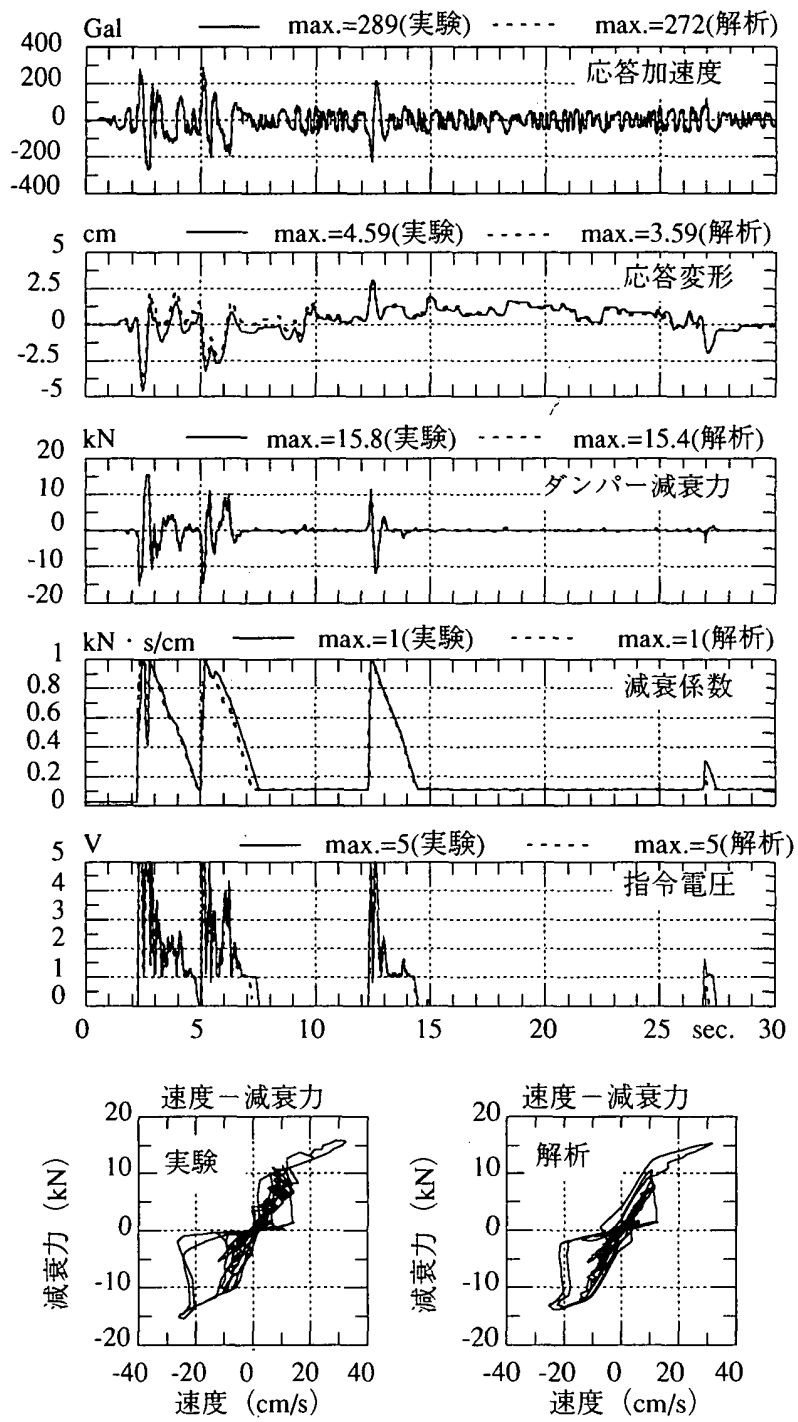

(a) El-Centro1940NS 加振 (400Gal)
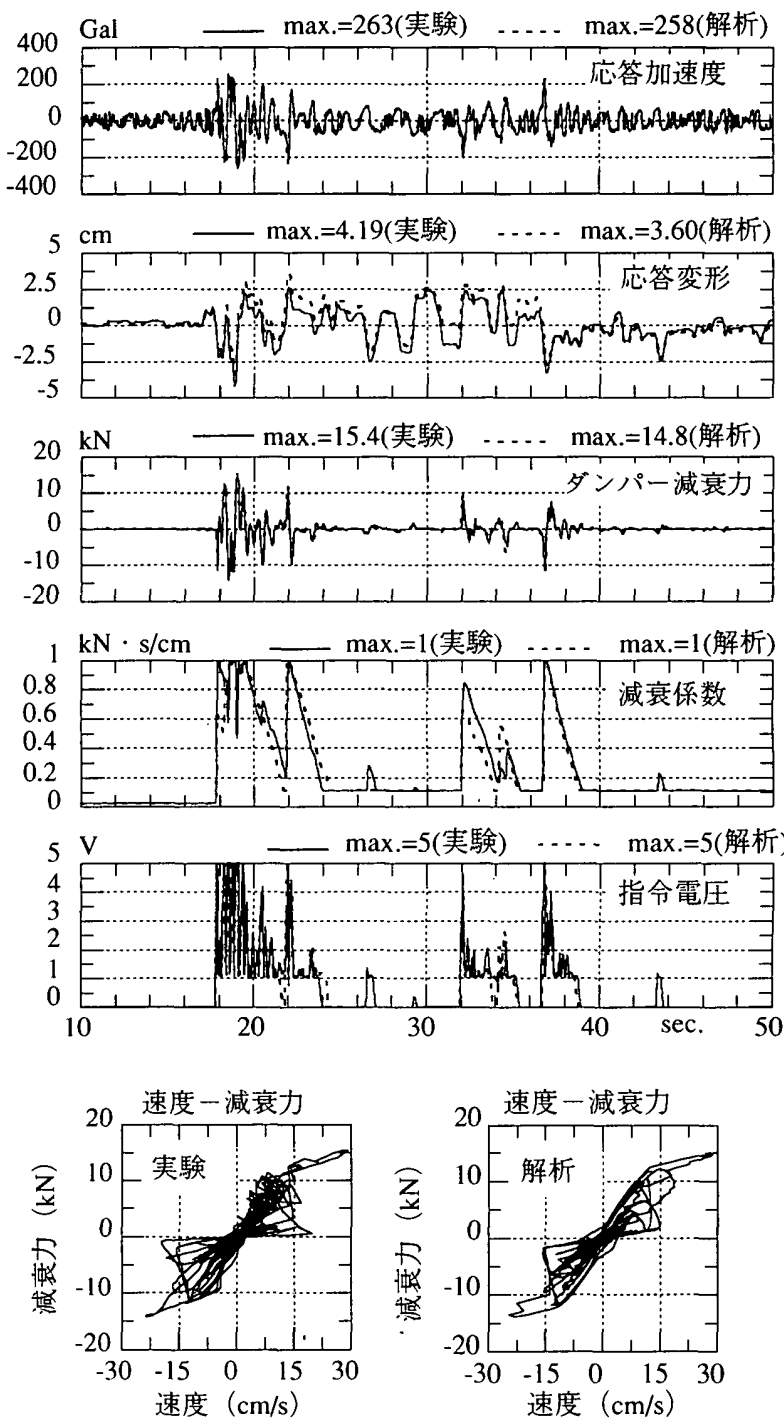

（b）Hachinohe1968NS 加振 (400Gal)

図 12 実験結果のシミュレーション 
揮させて,それ以上の加速度レベルで変形抑止が始まる設定にした が, 基準振幅值を増減することで, 免震効果を発揮させる入力加速 度レベルが調整可能である。

(3) シミュレーション

El-Centro1940NS と Hachinohe 1968NS の 400Gal 加振について, 免 震床の応答加速度, 応答変形, ダンパー減衰力, 減衰係数, 制御指 令電圧の時刻歴波形と,ダンパーのピストン速度一減衰力関係をシ ミュレーションした結果を図 12 に例示する。解析では, 制御指令 電圧に応じた減衰力が発生するまでの時間遅れとして, 3.1 の減衰 係数制御の場合と同じ $10 \mathrm{msec}$ を考慮している。

免震床の応答変形の増減に応じて減衰係数が切り替っており, 減 衰係数が大きな所では応答加速度も増大するが, それ以外では減衰 係数は小さくなり, 応答加速度が低減している。また, 解析結果と 実験結果は良く対応しており, 設定した力学モデルの妥当性が検証 された。

\section{5. 可変減衰ダンパーの制御法II}

3.2 で提示した可変減衰ダンパーの制御法は, 減衰係数を制約内 で連続的に切換える方法であるが, 使用する可変減衰ダンパーの構 造によっては減衰係数が不連続的に数段階にしか切換えられない場 合も想定される。免震床の変形が増大する可能性がある場合に, 直 ちに最大減衰係数に切換えて変形を抑止する方法も, 実用的には意 義があると思われる。そこで; 最も極端なケースとして, 減衰係数 が 2 段階にのみ切換え可能な (以下, 2 值切換え制御と呼ぶ) 可変 減衰ダンパーを用いた变形抑止制御について検討を行った。

\subsection{2 值切換え制御}

2 值切換え制御のアルゴリズムを図 13 に示す。Step6までは図 5 に提示したアルゴリズムと同じであり, Step7を下記の通り修正し ている。

Step7:減衰係数 $c_{i}$ が $c_{\min }$ の場合は, ダンパー減衰係数を下限值 $c_{\min }$ に設定し，それ以外の場合は上限值 $c_{\max }$ に設定する。

\section{2 振動台実験による性能実証}

2 值切換え制御と 3.2 の連続可変制御の性能比較を行った。振動 台実験の実験条件は以下に示す通り，4.3の地震波加振の場合と同 様である。

\section{（1）実験条件}

加振波 : El-Centro1940NS, Hachinohe1968NS

入力加速度：50Gal から $400 \mathrm{Gal}$ まで $50 \mathrm{Gal}$ ピッチで増加

2 值切換え制御：ダンパー減衰係数の上限值 $c_{\text {max }}$ を $0.5 \mathrm{kN} \cdot \mathrm{s} / \mathrm{cm}$ 及び $1.0 \mathrm{kN} \cdot \mathrm{s} / \mathrm{cm}$ の 2 種類に設定した。その他のパラメー夕は 4.3 の変形 抑止制御と同じに設定した。

\section{(2) 実験結果}

El-Centro1940NS と Hachinohe1968NS 加振の各々について, 入力 加速度に対する最大応答加速度と最大応答变形を比較して図 14 に 示す。図中には，アンロードと減衰係数一定制御（減衰係数 $c=1.0 \mathrm{kN} \cdot \mathrm{s} / \mathrm{cm})$, 並びに 4.3 の連続可変制御の結果を合わせて示し ている。両地震波加振共に $150 \mathrm{Gal}$ 加振までは, アンロードと同じ 最大応答を示している。200Gal加振以上では, 最大応答変形は頭打 ちになる傾向が見られ，400Gal加振時の最大応答変形は, アンロー ドの $50 \%$ 以下に低減されている。一方, 最大応答加速度は,

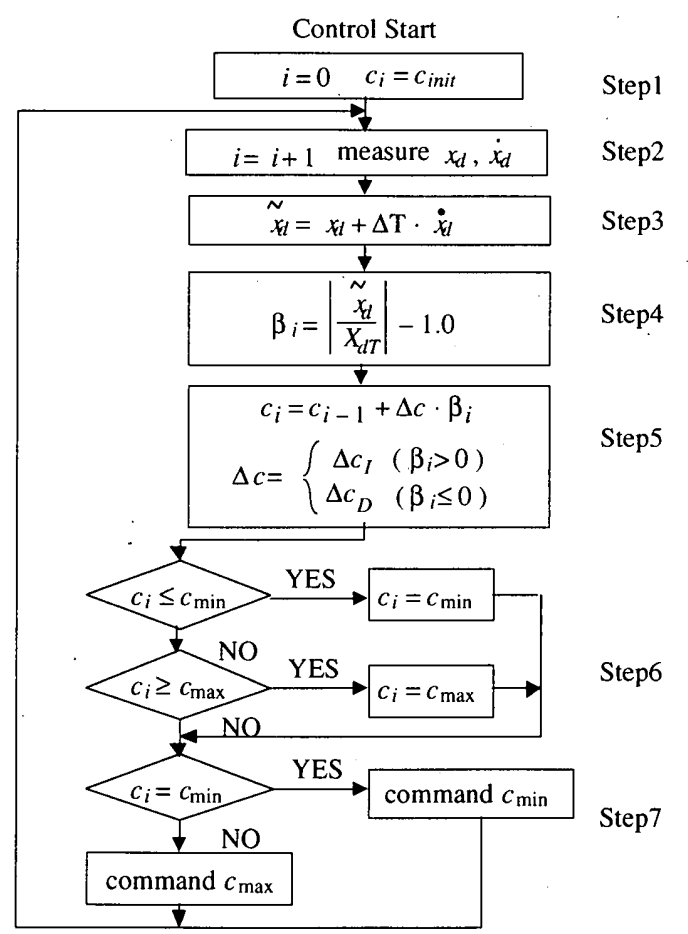

図 132 值切換え制御アルゴリズム

$c_{\max }=1.0 \mathrm{kN} \cdot \mathrm{s} / \mathrm{cm}$ の場合は急激に増加し, $c_{\max }=0.5 \mathrm{kN} \cdot \mathrm{s} / \mathrm{cm}$ の場合は 比較的緩やかに増加している。

最大応答変形の抑止効果は, 連続可変制御に比べると若干劣って おり, 入力加速度レベルの増加とともに比例的に変形が増加する傾 向が見られる。しかし， $c_{\text {max }}=0.5 \mathrm{kN} \cdot \mathrm{s} / \mathrm{cm}$ の場合は，概ね連続可変制 御に近い効果が得られており，減衰係数を2值に切換える制御でも 実用的には充分な性能が得られる場合もあると考えられる。

(3) シミュレーション

El-Centro1940NS の 400Gal 加振について, 免震床の応答加速度, 応答変形, ダンパー減衰力, 減衰係数, 制御指令電圧の時刻歴波形 と,ダンパーのピストン速度一減衰力関係をシミュレーションした 結果を図 15 に例示する。 $c_{\max }=0.5 \mathrm{kN} \cdot \mathrm{s} / \mathrm{cm}$ に設定している。

減衰係数が最大值に切換えられるタイミングを含めて, 解析結果 と実験結果は概ね良く対応しており, 設定した力学モデルの妥当性 が検証された。

\section{6. まとめ}

可変減衰ダンパーを用いて免震構造物の過大変形を抑止する制御 法を開発し, 床免震システムへ適用して, その有用性を振動台実験 により実証した。本研究の成果は以下の通りまとめられる。

1）可変減衰ダンパーの制御に, アクティブマスダンパーの振幅制 御用に開発した可変ゲイン制御法を援用し,ダンパー変形の基準振 幅值と一定時間後の予測振幅值を時々刻々比較して減衰係数を制御 することにより, 過大变形を抑止する制御法を開発した。従来のス トッパー式の変形抑止方法では, 衝撃的な過大加速度が生じる危険 が指摘されて来たが, 本制御によりこのような危険を回避して, 確 実に過大変形を抑止する効果が期待できる。

2）開発した制御法により，免震構造物の応答加速度と応答変形の 

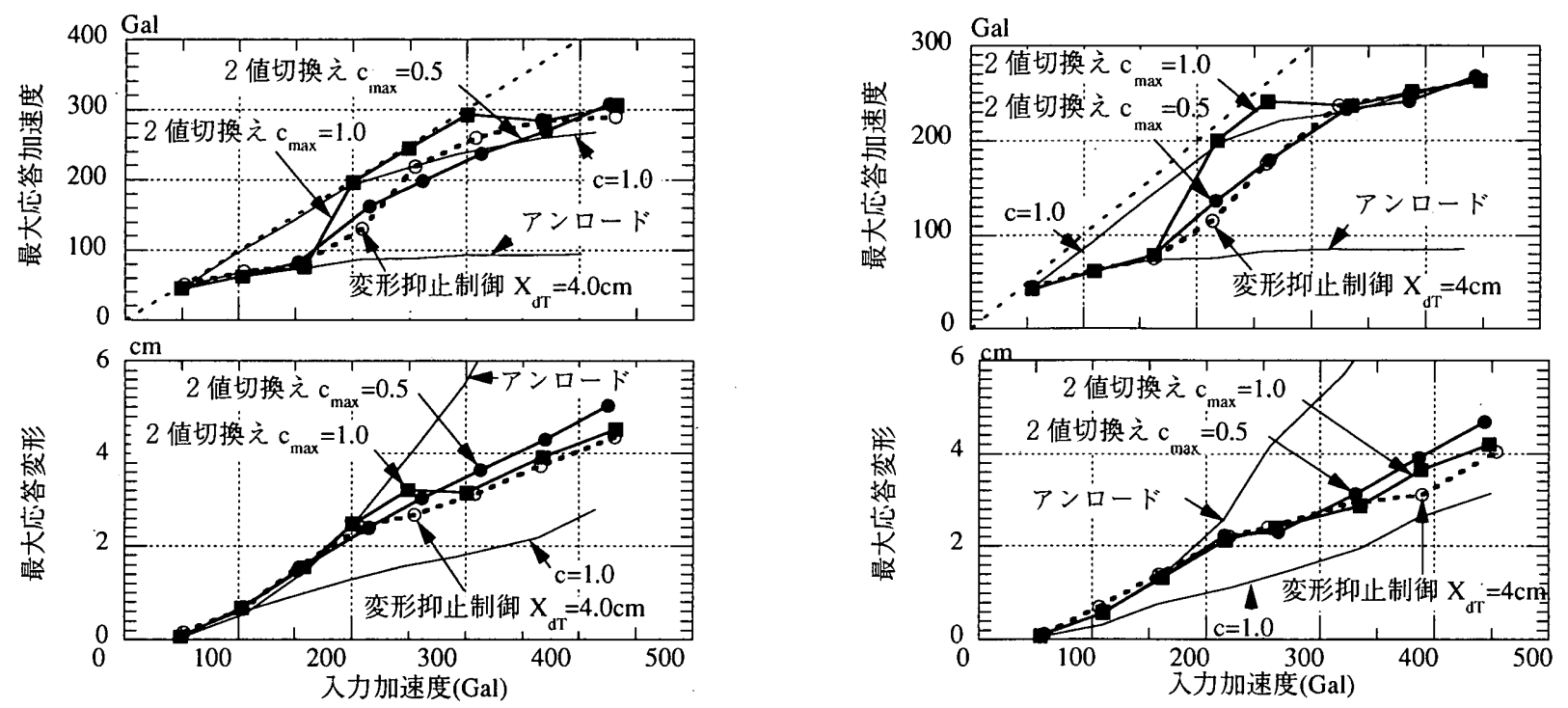

(a) El-Centro1940NS 加振

(b) Hachinohe1968NS 加振

図 14 入力加速度と最大応答
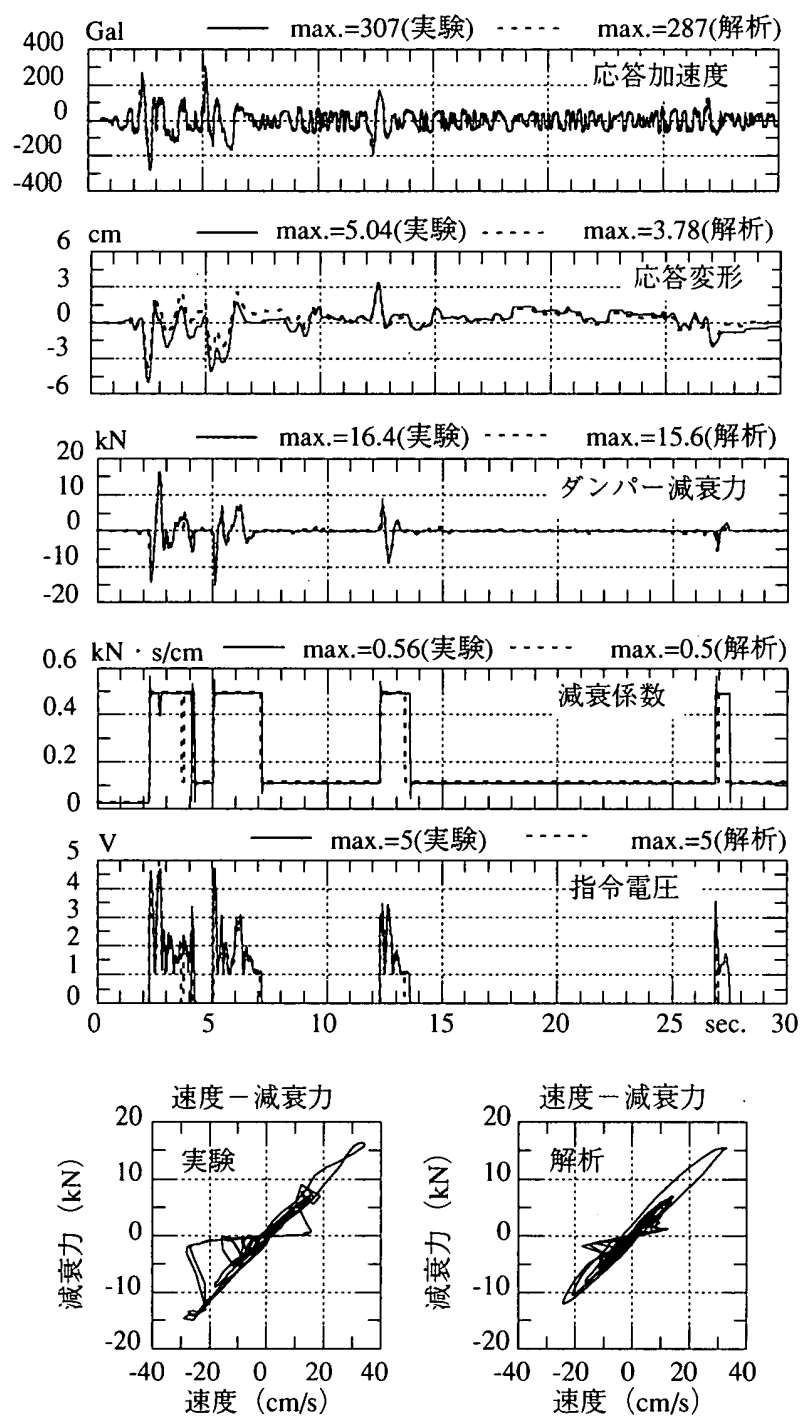

El-Centro1940NS 加振（400Gal）

図 15 実験結果のシミュレーション（2 值切換え制御）
トレードオフを考慮して, 性能調整できる効果を実証した。すなわ ち,ダンパー変形の基準振幅值を調整することにより, 許容变形値 と免震効果を発揮させる入力地震動の加速度レベルを調整すること が可能である。

3）可変減衰ダンパーと床免震システムの精度の高い力学モデルを 構築し，振動台実験の結果を精度良くシミュレーションできること を実証した。

4）本研究では, 減衰力が無段階に制御可能なオイルダンパーを使 用したが, 減衰係数を多段に切換えるダンパーへも本制御は適用可 能であり, 減衰係数を 2 值に切換える制御の有効性を振動台実験に より検証した。

なお, 本論文では, 床免震システムを対象として実証実験を行っ たが, 振動台性能とダンパー性能の制約から，地震波加振では 1 次 固有周期成分が充分励起されない,加振周期が卓越するような条件 下での実証実験となった。本制御法は建屋免震を含む幅広い免震シ ステムを適用対象とするものであり,長周期地震動により過大変形 が生じる可能性がある，建屋免震に適用した場合の性能について は，別途解析的な検討結果を報告する予定である。

\section{参考文献}

1) T. H. Heaton, J.F.Hall, D.J.Wald and M.W.Halling : Response of high-rise and base-isolated buildings in a hypothetical MW7.0blind thrust earthquake. Science 267, 206-211,1995.

2) J.F.Hall, T.H.Heaton, M.W. Halling and D.J.Wald : Near-Source Ground Motion and its Effects on Flexible Buildings. Earthquake Spectra, 11, No.4, 569-605,1995.

3）梶井丈史，迫谷政則，久田堂章：衝突を考慮した免震構造物の弾塑性 応答解析, 日本建築学会学術講演梗概集, B-2, 構造II, 527-528, 2000.

4）宮崎光生, 水江正：震源近傍の地震動に対して免震構造は対応可能 か?，第 28 回地盤震動シンポジウム，日本建築学会，119-136，2000.

5) T. Kobori, M. Takahashi, T. Nasu, N. Niwa : Seismic Response Controlled Structure with Active Variable Stiffness System. Earthquake Engineering \& Structural Dynamics, 22(9), 925-941,1993.

6) N. Kurata, T. Kobori, M. Takahashi, N. Niwa, H. Midorikawa: Actual Seismic Response Controlled Building with Semi-activeDamper System. Earthquake 
Engineering \& StructuralDynamics, 28(11), 1427-1447,1999.

7）栗野治彦，田上淳，清水幹：エネルギ吸収能力最大化を目的としたセ ミアアクティブオイルダンパ，第 2 回日本制震（振）シンポジウム， $77-84,2000$

8）西谷章, 仁田佳宏, 池田芳樹, 伊藤敦史, 欄木龍大：可変スリップレ ベルダンパの概念によるセミアクティブ振動制御に関する基礎的研究， 日本建築学会構造系論文集，558，93-100，2002.

9）藤田隆史, 壁矢和久, 速水浩, 相沢覚, 東野雅彦, 久保智史, 羽生田 信良, 森孝之：可変摩擦ダンパを用いたセミアクティブ免震構造の研 究 (第 1 報 可変摩擦ダンパの開発とセミアクテイブ制御システムの 基礎的研究)，日本機械学会論文集 C 編, 57(536), 1122-1128，1991.

10) M.Q. Feng, M. Shinozuka, S. Fujii : Friction-controllable Sliding Isolation System, Journal of Engineering Mechanics, ASCE,119(9), 1845-1864 ,1993.

11）藤田隆史, 榊和彦, 洞宏一：ピエゾアクチュエー夕を用いた摩擦力制 御形アクティブ・ブレースによる構造物の振動制御に関する基礎的研 究, 日本機械学会論文集 C 編, 63(614), 3467-3471，1997.

12) J.A.Inaudi : Modulated Homogeneous Friction: A Semi-activeDamping Strategy. Earthquake Engineéring \& Structural Dynamics, 26 (3), 361-376 1997.

13) B.F. Spencer Jr., S.J.Dyke, M.K.Sain, J.D.Carlson:Phenomenological Model for Magnetorheological Dampers.Journal of Engineering Mechanics, ASCE, 123(3), 230-238,1997.

14) L.M. Jansen, S.J. Dyke : Semiactive Control Strategies for MRDampers: Comparative Study. Journal of Engineering Mechanics, ASCE, 126(8), 795803.2000.

15）潘公宇, 松久寛, 本田義久：磁気粘性流体を用いた減衰可変ダンパに よるセミアクティブ振動制御, 日本機械学会論文集 C 編, 67(656), 978-984, 2001

16）岩田範生, 曾田五月也, 袖山裕, 砂子田勝昭, ·藤谷秀雄：バイパス式 MRダンパの力学特性に関する実験的研究, 第2回日本制震(振)シンポ ジウム論文集， $15-20 ， 2000$.

17）森下信，浦環：構造物のセミアクティブ制振システム,アクティプ制
震(振)シンポジウム論文集，325-332，1992.

18）福喜多輝, 田村和夫，林章二，柴慶治：電気粘性流体を用いた回転型 可変減衰装置のセミアクティブ制御に関する研究, 構造工学論文集, 41B: 23-32, 1995.

19) B. Zhao, X. Lu, M. Wu, Z. Mei : Sliding Mode Control of Buildings with Base-isolation Hybrid Protective System. Earthquake Engineering \& Structural Dynamics, 29(3), 315-326, 2000.

20）三東儀洋, 鈴木隆典, 吉田和夫：外乱包含双線形最適切換え面を用い たスライディングモードセミアクティブ免震, 日本機械学会論文集 C 編, 68 (674), 2851-2858, 2002.

21) G.Leitmann : Semiactive control for vibration attenuation. J. Intelligent Mat. Sys. and Struct.,5, 841-846,1994.

22) S.J.Dyke, B.F.Spencer, M.K.Sain and J.D.Carlson : Modeling andcontrol of magnetorheological dampers for seismic response reduction, Smart Mat. and Struct., 5, 565-575, 1996.

23) J.N. Yang, J.-H. Kim, A.K. Agrawal:Resetting SemiactiveStiffness Damper for Seismic Response Control. Journal ofStructural Engineering, ASCE, 126 (12), 1427-1433,2000.

24）内田勝，村田充，原靖彦，暒谷泰史：電磁比例リリーフ弁方式セミア クティブ・サスペンションシステム,カヤバ技報, 第26号, 30-33, 2003.

25）長島一郎，西山正三，篠崎祐三：アク宁ィプマスダンパーを用いた建 物の振動制御（その 2 ），日本建築学会構造系論文集，第 483 号，3949, 1996.

26) Q.Feng, M.Shinozuka, S. Fujii and T. Fujita : A hybrid isolation system for bridges, The first U.S.-Japan workshop on earthquake protective systems for bridges, 323-336,1992.2.

27) A. Mokha, M. Constantinou and A. Reinhorn: Teflon bearings in aseismic base isolation : Experimental studies and mathematical modeling. NCEER88-0038, 1988.12.

28) I. Nagashima et. al.:Performance of hybrid mass damper system applied to a 36-storey high-rise building. Earthquake Engineering \& Structural Dynamics. 30(11), 1615-1637, 2001 . 